\title{
The Authority On Endorsement Of Marriage Agreement Between Indonesian And Foreign Citizen Which Made Abroad
}

\author{
Fitri Khairunnisa \\ Magister Kenotariatan Universitas Brawijaya \\ Jln. Veteran Malang, Brawijaya, Malang, Jawa Timur \\ Email :fitrikhairunnisa19@gmail.com
}

\begin{abstract}
Every citizen is entitled to marry with anyone either with fellow Indonesian Citizens or with Foreign Citizens (WNA), as long as the marriage is held in accordance with the provisions of applicable law in Indonesia. The method of this research using a normative legal method which are conducted the file through library conduct and regulation, by find the meaning and requirement to do the prenuptial agreement. a prenuptial agreement is an agreement between two person to arrange their personal property made before, during or after marriage, and authorized by the marriage registry officer. The marriage agreement, which was then made abroad, then created a problematic one for who was authorized to legalize the marriage agreement to then have legal force in Indonesia.
\end{abstract}

Key Words : marriage agreement, Foreign citizen, registry officer

\section{INTRODUCTION}

Marriage is a consolidation between men and woman. Marriage also legally known as an agreement on a household relationship as a husband and wife, witnessed by some people and lead by a trustee. ${ }^{1}$ Marriage is not only linked with a wife or husband personality but everything on the family matters and people. The understanding on marriage by virtue of article 1 act Number 1 of 1974 on marriage ( known as UUP) stated that " marriage is an inner bond between men and woman as a husband and wife in purpose to make a family or a happy and eternal household by accordance to the deity".

The people who is bound in marriage in accordance to the Islamic law, a record is keeping in the office of religious affairs to get the marriage act as a prove of the marriage existence. While for them who is a non moeslim a marriage record is performed in the registry office. After performing marriage vow or ijab Kabul for the muslims then the marriage is legitimate whether under the religion and people faith. Marriage is a sacred event which will be through for every human in their lifes. Wealth and property are one of the most important things in marriage life, so for this reason the marriage act (UUP) govern every aspect which is linked with the property in marriage.

Tim Prima Pena.(1993). Kamus Lengkap Bahasa Indonesia, Jakarta: Gitamedia Press, p. 468 
Human is created with their diversity, the existence of ethnic ifferences, cultures and religion. Mixed marriage also spread in every social of the people. The global information, economic factor, education have dropped the opinion that saying "a mixed marriage is performed between European, foreign east and indonesian. Generally, the reason that caused every couple to have a different citizenship performing marriage one of the factors is an introduction through a the social media, or a working/business partner, or getting know each other on the vacation, a friend from school/college era. A mixed marriage also occurred between Indonesian labour with foreign worker from another country. ${ }^{2}$

Mixed marriage is set under article 57 UUP stated that "The meaning of mixed marriage under this act is a marriage between two people in Indonesia subject to other law, because the citizenship differentiation which one of the party as indonesia citizen. A mixed marriage cannot be performed before the marriage requirement is satisfied by the laws on each person, proved with the explanation letter explaining that all the requirement is fufilled by the authority who recording marriage record according to the applicable law for each party.

Indonesian citizen has the rights to perfroming marriage with anybody whether with the same citizen or foreigner, as long as the marriage is performed by virtue of the applicable law in Indonesia. In accordance with the defition under article 57 UUP it can be spelled out the elements of mixed marriage as follows :

1. A marriage between men and women;

2. Performed in indonesia and subjected to other applicable laws;

3. Because the citizenship differentiation on one of the parties;

4. One of the parties is indonesian citizen.

An Indonesian who married with foreign citizen, after the marriage is prohibited from owning a land which is property rights. It is accordance with article 35 UUP which stated that the property that the couple gain on the marriage bond turn to joint properties. It will be a mixed property after marriage. As the qonsequences, a foreign citizen will also enjoying or owning for the property. However, analyzing from the act number 5 of 1960 on the basic regulation on the agrarian subject matter, a foreign citizen cannot have a property rights of a land. As the legal consequences, an Indonesian who married with foreign citizen, after the marriage can no longer obtain property rights over a land, because it will turn into joint property between the couple. An Indonesian wife or husband citizen with foreign wife or husband citizen, who separated their property before marriage is perform, then the wife or

2 http://www.mixedcouple.com, accessed on desember $9^{\text {th }} 2017$ 
husband under Indonesian citizen will not lost his rights to own a property rights over a land which is a property rights (HM), because the mixed property will no longer applicable since there is no mixed property between the husband and wife who bound under foreign citizen.

In the practice of making a marriage agreement, there are a few things which commonly agreed and poured in the covenant of marriage, i.e :

1) Any default property on marriage, either all of the business result from each party as well as from grants, beneficiary or freely obtained of each party at the time of marriage.

2) All debts carried by the spouses in the marriage which brought by each party at the time of marriage is still going to be dependents of husband.wife.

3) A wife will take care of his personal property either it on the form moving objects as well as in the form of objects that does not moving on the task to gain and enjoying its result and revenue whether the property even her work or from other resource; to taking care of all the things regarding her roperty, a wife does not need any help or permission or authority from her husband;

4) The responsibility on economic matters is carried by a husband to provide a living for his wife and children

5) A responsibility regarding the children education which born in the marriage

6) Etc.. ${ }^{3}$

The provision on marriage agreement have listed under chapter 7 fro article 139 to the article 167 on the civil book, chapter VII article 45 to the article 52 on the compilation of Islamic law and chapter V article 29 act No 1 of 1974 on the marriage. The civil book stated that a marriage agreement is an agreement that actually on the contradiction from a principle/regulation regarding the joint on property of spouses at the time of marriage, as far as the marriage agreement is not abusive the good moral or a public interest. Therefore, a marriage agreement is a contradiction of the regulation on chapter VII article 35 and 36 of marriage act stated that a property that obtained during the marriage will turn to a joint property, a default property of each husband and wife and the property that obtained from each husband and wife and the property that obtained as a grants or beneficiary are under each supervision as long as the parties are not specify other". Further, article 36 of marriage act stated that :

3 http://www.indonesianotarycommunity.com/perjanjian-perkawinan/ accessed on desember $10^{\text {th }} 2017$ 
1) Concerning the joint property, a husband or wife may acted under the approval by the parties.

2) Concerning any default property a husband or wife have a full rights to form any legal act on their property.

The marriage act does not contain any regulation regarding the contents of marriage itself. The act only determines that a marriage agreement must not violated the law, religion and morals in the society. According to the supreme court advisory opinion, a civil book that regulated marriage matters is seen to be valid as long as it not contradicted with the marriage act.

Bain accordance with the opinion of the Supreme Court (MA), KUHPer who regulates everything in the marriage is seen to be valid as long as it does not contradict the UUP.sicly, the civil book provide freedom for the parties to specify the object of the marriage agreement. However the marriage agreement should be made according to the regulation, as follows :

1. It is not contain matter that against the norm and morals in the society.

2. The marriage agreement is prohibited to reduce/eliminate a rights that come up from a husband authority, which is a husband rights in determining a living place or a husband rights to take care of the marriage joint property.

3. Reducing the rights which will merge from the parents authority.

4. Reducing the rights which determined by the regulation for husband or wife who live the longest.

5. Not made the promises which contained rights extrication of the property. The relics of their family on the lower line.

6. Not made a promise which stated that one of the party will bear a bigger debt then his part on the active.

7. Not made a promise on the general terms that the marriage property will be subject to the foreign regulation as well as the regulation that have been applied in Indonesia or netherland, as well as by the customary law. ${ }^{4}$

Under the act it is only determines two types of elimination of the joint roperty, that are :

1. Sharing the profit and loss. This matter means that the husband and wife brought each of their default property, a property that they obtained before marriage, also a grants, grants fund and beneficiary as a result at the time of marriage. While the property and debt that they obtain at the time of marriage will belong to both of the parties.

$4 \quad$ Article 147 Kitab Undang Undang Hukum Perdata 
2. Togetherness of result and income. This marriage agreement is similar to profit and loss togetherness. However if there is a loss at the time of marriage, then only a husband who will bear it, while a wife is free from the loss.

In terms of authority and registration on marriage agreement mechanism between Indonesian and foreign citizen which made abroad is not regulated further. Which agency that has the authority to confirm the agreement by according to Indonesian law. The contents of the agreement is freedom of contract without violated the applicable law in Indonesia.

\section{METHOD}

Types of research: The normative legal research is a research that analysing law regulation in a coherent of legal order. ${ }^{5}$ Approaching Concept : As a normative-prescriptive legal reserach which concern about the prenuptial agreement, various approach namely legal approach (statute approach) which are analysing and researching the rule of act that concerning the form on prenuptial agreement as well as another regulation that related with the prenuptial agreement. Secondly, a conceptual aprroach is to analyze the concept and requierement which related with the research.

\section{ANALYSIS AND DISCUSSION}

Generally, prenuptial agreement contains regulation on the property of the husband or wife candidate. In principle the understanding on prenuptial agreement has the same character with other agreement generally, which is an agreement between two candidates of husband and wife to arrange their property which performed before marriage, as well as confirmed by the marriage registrator. The prenuptial agreement under marriage act is regulated under chapter $\mathrm{V}$ article 29 that contains four sections, i.e.c:

Section (1): at the time or before the marrage performed, both of the parties on the mutual agreement may perform written agreement and confirmed by the marriage registrator, after the matter is also applicable for the third party as long as the third party is linked with the agreement.

Section (2): the agreement cannot be established if the agreement violated the law , religion and norm limitation

Section (3): the agreement is applicable since the marriage is perform.

Section (4) : as long as the marriage take place the marriage cannot be change, unless if both of the parties agreed to make a change and the change should not harm the third party.

\footnotetext{
5 Soetandyo Wignjosoebroto.(1995). Sebuah Pengantar Ke Arah Perbincangan Tentang Pembinaan Penelitian Hukum Dalam PJP II, Jakarta : BPHN Departemen Kehakiman, p. 5.
} 
Although there is no clear definition that can explain a marriage agreement but constrained, aas the legal relation concerning the property of the parties, in terms on one of the parties promises to perform a thing, while on the other hand is entitled to implement the agreement. Specifically, it can be said that the marriage agreement is an agreement made by a prospective husband and wife at the time or before the marriage is held, which agreement is made in writing and authorized by the marriage registrar and the contents also applied to the third parties as long as it is agreed.

In 2015, the constitutional court through the court decision number 69/PUU-XIII/2015 decides on a matter of altering the concept of marriage arrangement that has been previously set up by the marriage act.

In 2015, the court of law through the Court Decision Number 69 / PUU-XIII / 2015 decides on a matter of altering the concept of marriage arrangement that has been previously set up by the UUP. It was decided that the constitutional court decision was a legal renewal in the field of marriage. Article 29 of marriage act stated that marriage agreement can only be made before marriage or at the time of marriage. However, with the decision of the constitutional court, the marriage agreement may be carried out during marriage.

It was decided that the Constitutional Court's decision was a legal renewal in the field of marriage. Article 29 UUP marriage agreements can only be made before marriage or at the time of marriage. However, with the decision of the Constitutional Court, the marriage agreement may be carried out during marriage. Through the constitutional court decision, it can be seen that the constitutional coirt have relaxed the terms of marriage on the marriage agreement, although the marriage was not preceded and there was no agreement on the marriage agreement, a marriage agreemenet and there was no agreement on the marriage agreement, a marriage agreement could be made during the marriage.

The constitutional court decision was born since the granted of a part of the petition which submitted by Indonesian applicant who married with foreign citizen, on behalf of Mrs. I Farida based in East Jakarta on June 24, 2015. The case presented that Mrs. Ike Farida was married to a Japanese fpreigner without a marriage agreement either before or during the marriage. until finally during the marriage Mrs. Farida decided to buy one unit of apartment in Jakarta. However it says on the application that after the applicant have pay off the apartment but the apartment was not handed by the developer so disadvantageous the applicant, the developer reason was because the applicant husband is a foreign citizen which basicly there is no default property agreement.

The applicant felt that her position after marriage with a foreign citizen without 
marriage agreement have been harmed because her rights to have an asset been obstructed. This made the applicant filed her oobjection.

The provision number 1.1 and 1.2 of the constitutional court ruling decision Number 69/PUU-XIII/2015 stated that " at the time before the performing or during the marriage both of the parties under their agreement may applied a written agreement which authorized by the marriage registrar or a notary, after the contents is applicable for the third party as long as the third party is linked with the agreement".

This provision then revises the marriage agreement that can be made after the marriage and revises article 29 section 1 of marriage act which stated that a marriage agreement is perform written and authorized by the marriage registrar as long as it contains the third party as well. However, under this constitutional court decision an addition of "or notary" which means the vision of a choice between who have the rights or authorization to authorized the marriage agreement. The position between a marriage registrar and notary considered equal. According the frase position, it enable to have a written agreement on the authorized of a marriage registrar or notary.

The formation of written agreement on this provision means on two types of the private agreement and authentic agreement. A private agreement means the agreement is ade according to the mutual agreement, while the authentic agreement means that the agreement is made in front of the notary which then have the perfect strong proof. The existence of both types of the written agreement may be understand from this provision that a marriage agreement may be made privately or in front of the notary which will resulted an authentic deed. According to the deed, it may understood that in the deed, a notary only acted to pour the intention of the parties into the deed, so then it contains and the truth in the deed is pure as the responsibility of the parties who made the deed.

The phrase on the constitutional cort decision " a written agreement that authorized by the marriage registrar or notary" defined that there is equalization of authority of a notary nor the marriage registrar, wheres in authority between a notary and a marriage registrar is very different. By virtue of the notary official act a notary authority is only authenticating signature and assign the exact date under the provate deed by register it in the particular book. This matter arise an overlap between authority so it provides law uncertainty in the process making of marriage agreement.

A marriage agreement purpose is to provide law protection, which is as a law for the parties with good faith intentions. If one day arises a disput between the parties, it can be a 
reference and one of the base each parties on performing and provide limitation of the rights and duty between them. According to the previous deiscussion that a marriage agreement is regulated under Indonesian law which are article 29 section 1,2,3,4 and marriage act article 1313 and 1314 of the civil book on the agreement from a contract. Along with article 1320 of civil book on the legal terms of agreement.

Concerning the property of marriage, there are two types of ownership of the property which are joit property and personal property of each husband/wife. The marriage act regulated that a husband/wife joint property is a property obtained at the time of the marriage, while a default property is a personal property, including a grants or heritage property. Whilst, the civil book stated that joint property is the whole husband-wife property (before or during the marriage) whether in te form of passive active assets, except concerning inheritance or related inheritance or excluded grants, which can be categorized as a personal property.

The unty principle of a property in the civil code strictly abolished or in other words that a spouses may perform a fully property separation or only related with profit and lorss or revenue.

Article 119 of the civil code strictly stated that since the marriage is perform, then according to the law occurred the joint property thoroughly between a husband and wife, as far there are no other provision in the marriage agreement.

It may understandably since the civil book considering a marriage as a consensual bond outwardly. A marriage is seen purely as an agreement. Therefore, it reasonable if theprinciple of property unity in the marriage can be deniable.

As listed under marriage act on the property in marriage, article 35 section 1 only strictly said that a property obtained during the marriage is a joint property. Unlike the regulation on the civil book, in the matter of joint property, the marriage act does not provide a choice for the parties to specify other thing. Moreover, in the section on the default property or grants or heritage property is under each authority as long as the party does not specify others. The defilnition on object mastery can be defined as physically or juridically mastered.

According to the article 35 on marriage act, the section 2 strictly said that only on the default property can be arrange differently, in means that the parties may agreed that the default property excluded from joint property by making a marriage agreement while the joint property, the marriage act does not specify the ability of the provision to be excluded by the parties. It can be seen that the marriage act is less assertive on the matter of joint property separation through the marriage agreement. However, it may considered that the joint property cannot be countered in any ways by the parties. Thus, according to the marriage act, 
a marriage agreement actually made to unite the property as a whole, either as a joint property or default property. Different from the civil book, a marriage agreement is made to make a property separation from the unity of the property.

Eventhough the provision on joint property under marriage act cannot be changed as a separation on property, on this matter can be understandably since the marriage purpose according to marriage act is to get the spiritual and material welfare, whilst under the civil book, a marriage is only seen from the civil aspect, that even if the parties are agreed (consensual).

Escaping from those all, the separation on property agreement is important when it linked with a property which arranged complex, such as a land. Under the agrarian according to the basic agrarian law, the land ownership also regulated for who can own the land (land subject, particulary for the foreigner). On the other hand, on the marriage it possible occurred a marriage with different zitizenship (mix marriage) thereby the agreement on property separation is better provided whether regarding his own property or the time, not only before or at the time performing marriage as decided by the constitutional court as well as after the marriage.

According to the article 56 (1) of maariage act, stated that a marriage which performed abroad (outside Indonesia) is legitimitae if : the marriage is performed according to the applicable law in the state where the marriage is performed and for the Indonesian zitizen by not violated the marriage act in Indonesia.

Indonesian citizen on his comeback to Indonesia should reporting to the impelemnting agency on the domicile place by brought the report proof data or an abroad marriage registration, and the excerpts of marriage deed issued by Indonesia representatives agency, along with the marriage agreement as regulated under article 56 section 2 of marriage act number 1 of 1974. According to article 29 section 3 of marriage act number 1 of 1974, a marriage agreement is applicable since the marriage is performed. This is accordance with article 73 of presidential regulation number 25 of 2008 stated that for the marriage registration abroad, reporting letter issued by Indonesian embassy in the palce where the marriage performed at least 30 days since the concerned back to Indonesia, this is accordance with article 37 section 4 act number 23 of 2006 on the citizen administration.

A marriage witnessed by the embassy official or Indonesia consulat official abroad, the notification will be held for at least 10 days to the consulat or indonesian embassy representative before the marriage is performed, the registration by the embassy official does 
not mean directly registered in the registry of both couple, because the act determines that after the couple back to indonesia, in one year the marriage have to registered in the marriage registry office.

The terms of foreign element have a conncetion with a marriage, which are :

1. Difference in citizenship or domicile from the prospective husband and wife.

2. The marriage was performed abroad (foreign state) not in the domicile state of the prospective husband wife.

To determines the aterial law which country will be used for a marriage with a foreign element (international) including a marriage which performed outside indoneisa because under the principle of Locus Regit actum possibly arises a problem if it has different citizenship or different of marriage law as well as will arises a conflict of law and have to be settled with international civil law. ${ }^{6}$

According to the acrticle 56 section 1 of marriage act stated that " a marriage performed outside Indonesia between two people of Indonesia and foreigner is legitimitae if performed according to the applicable law where the marriage is performed" the words is more in view of lex loci celebrations principle wich is determines that the legitimate marriage is according to the material law from a state or place where the marriage perform and inaugurated.

For the marriage that performerd abroad and does not violated the marriage act, according to section 2 above stated that "within one year after husband and wife return to Indonesia, their marriage letter must be registrate in the marriage registry office of their domicile as applicable on the regulaton. As referred to is a letter proof of marriage of Indonesian citizen or reporting proof or marriage registration abroad and quote of the marriage deed. Likewise according to ministry of home affairs regulation number 12 of 2010 , concering the guidelines for marriage registration and reporting of deeds issued by other countries, article 14 paragraph 2 stated that reporting must also satisfied with:

1. Family cards and identity cards (KK, KTP).

2. The reporting proof from Indonesian embassy.

3. Citation of civil registration deed.

Marriage registration is done with an Indonesian citizen fill the marriage registration form by submitted or showed the requirement of consuler official, then the consuler official write down on the marriage deed registration and issued quote of marriage deed, Indonesian

6 Badan Pembinaan Hukum Nasional Departemen Kehakiman,(2005), Jakarta: Gramedia, p.29 
citizen after return to Indonesia must do a report to the implanting agency or civil registration office or religious affairs office as adjusted with the regulation, particularly for the moeslims it goes to religious affairs office and non moeslims goes to the civil registration office.

On the registration of marriage and marriage agreement for the couple who has difference citizenship which performed abroad it known an expiration to get the law certainty. In order to get marriage registration and marriage agreement there are some regulation that they have to obeyed to get the law certainty which is atleast 1 year for them to registrate their marriage as well as their marriage agreement in the marriage registration office as regulated under article 56 paragraph 2 of marriage act.

A sovereign state must have its own law system which difference with other state, this differences as the consequences of the history line which experienced by each country differently. So for the norm that the people follows as the law base, it can be sure its level and type is not solid. Every country's law is summarized under the system which no other than sets interrelated components. it means that every law system in the country consists of tangible components of law, such as administrative law, criminal law, civil law and etc. a legal field will be interrelated with other legal fields as a whole and comprehensive entity. ${ }^{7} \mathrm{~A}$ component of law surely will be devided into smaller subcomponents, from its all it will be interrelated as a whole entity. With the hierarchy, then each field of law will held independent characteristic, but not released from other field of law. Even in some conditions, the relation between the law field often contributed an explanation as one form of synergy between them. The law of a country which is arranged based on the certain systematics, cannot be separated from a state sovereignity miletones, in order to regulate its citizens. ${ }^{8}$ Through the legislation, it hopes the welfare and discipline will happen as the regulation listed.

An authority is very important part and as the first part of administrative law, because the government (administration) will only able to carry out its authority function as regulated under the law. According to SF Marbuh ${ }^{9}$, an authority has a meaning of the ability to perform an action of public law or juridically as ability to do an action provided by the applicable law to do law relations. Therefore, the government authority has properties as follows: ${ }^{10}$

Gatot supramono.(2006). Hukum Orang Asing di Indonesia, Yogjakarta: Sinar Grafika, p.123

Ibid., p. 25

SF Marbun, Peradilan Administrasi Negara danUupaya Administrasi di Indonesia, Jogjakarta: Liberty, p. 54-55.

Ibid.

118 Fitri Khairunnisa| [The Authority On Endorsement....] 
1. Ekspress implied.

2. Has a clear purpose and meaning.

3. Bound to a certain time.

4. Subject to written and unwritten legal restriction.

5. The contents of authority can be general (abstract) and concrete.

An authority is a core concept on the constitutional law and administrative law, because under the authority contains rights and ability even under the constitutional law descripted as the law power. It means only authorized action (according to the authority) which may get a law power. Concerning the law power, there are two two things which need to descripted which is linked with the authorization of government action and law power, both of it interrelated. "legal" is an opinion or statement about government action, whilst "law power" is something which concern on its verb (the area and its influence). The government action is legal if its accepted as a part and law order, and a government action has a legal authority if its able to influence law society. ${ }^{11}$

According to the explanation above, the authority on marriage agreement divided on:

1. The officer of marriage registration are the civil registrar and the official on religious affrair

2. A notary

Concerning the marriage agreement that made abroad, there is no provision which regulated whether the marriage agreement will have the legal bound Indonesia if its registrated and authorized according to the Indonesian law or the marriage agreement that made abroad cannot be legalized also registrated in Indonesia so that the spouses must remake the new marriage agreement according to the Indonesian law.

According to the author, the nature of the marriage deed which made abroad tend as the under hand deed so there must be a process passed so that the marriage agreement can apply in Indonesia. The process is done by legalization in front of a notary and then do the deed registration in the officer of marriage registration which is the official of religious affairs, for the Indonesian and foreign citizen moeslim couple or civil registration for the non moeslim couple, therefore the registrated deed may applicable as well as for the third party including all of the matters on the agreement.

The function of marriage registration abroad is in order to issues the letter proof of

11 Jazim Hamidi.(2006). Hukum Keimigrasian Bagi Orang Asing di Indonesia. Jakarta: Sinar Grafika, p. 39 
marriage registration from consulate of Indonesia as the legitimate proof of the marriage that performed officially abroad. The couple have to pass the system. The official who has the important rule on the marriage that performed outside Indonesia is the embassy official or official of the consulate general of the Indonesian republic where the couple performed their marriage. the authority of this official is to represent the position of marriage registrar. ${ }^{12}$

The official of marriage registrarabroad has the authority to implement the mandate that have been bestowed upon him and has the important role in determine marriage record for the couple that performed their marriage abroad. The function of the function of the marriage official abroad is the same which is to authorized or witnessed the marriage, however they does not have the absolute authority regarding the registration on marriage record, but according to the duties changes of the civil registry office in Indonesia which only records marriage, a consulate should not endorse a marriage between Indonesian and foreign citizen, it is enough with record it in the marriage deed then record it in the marriage deed register. In this case, the relevant consulate general cannot let his hands down, his function and duty to protect and help his citizen in preparing either the license or information, passport and etc in order to perform the marriage. ${ }^{13}$

The formal procedures of the marrieage which held in front of the consulate general or representative of indoneis is applicable for the marriage of Indonesian citizen which performed abroad so that its not violated the provision of the law as well as to prevent the legal smuggling, in the further research the consulat official or embassy official of republic Indonesia, first check the two of prospective differences in citizenship before marriage especially for the Indonesian citizen who will get married mus satisfy the requirement of particular material, general and formal also accordance with the article 2 paragraph 1 of marriage act, and when the requirement are fulfill on the marriage, then the couple will get the marriage regisrataion book.

The report of marriage made long before the day of marriage, then the prospective couple must inform the local representative of republic Indonesia. When the marriage is held it will be record by the representative and local authority agency. The marriage will be record or reported to the representative of republic Indonesia by fulfilled the requirement of the copy on: ${ }^{14}$

1. The proof of marriage registration or from local state

Supani.(2015). Diskursus Pencatatan Perkawinan,Yogjakarta: Dee Publish, p.27

Ibid.

Article 70 Undang-Undang Perkawinan no 1 Tahun 1974 
2. The Passport of Republic Indonesia

3. The identity card (KTP) of husband or wife as the indonesian citizen

To legalize the marriage so that it can be registered by authorized marriage registrat, then for every indonesian citizen who held the different on citizenship abroad, have to fulfilled several requierement and procedures as regulated under marriage act article 56 paragraph 1 and 2. The marriage registrar abroad who witnessed the marriage, therefore with the legal marriage they make marriage records abroad are carried out by fulfiling the requirement of presidential regulation number 25 of 2008 on the requirement and procedures of citizen registration and civil record which are:

1. The certificate letter of the occurrence of marriage in the state

2. Passport photos of husband and wife

3. Photo copy of passport of republic indonesia

4. Photo copy of identity card (KTP) of husband and wife ${ }^{15}$.

The marriage registration as means is done with procedures of :

1. The Indonesian citizen fill the form of marriage registration by handed and or showed the requirement to the official consulate.

2. The official consulate write on the register deed of marriage and issued the quote of marriage certificate or proof letter of the information on marriage. ${ }^{16}$

Indonesian citizens afer returning to Indonesia report to the executing agency in the place of domicile by bringing proof of data reporting or marriage registration abroad and the quote of marriage deed which issued by the representative agncey of republic Indonesia as stated under article 56 paragraph 2 of marrage act number 1 of 1974. For the marriage record abroad, the reporting letter issued by Indonesian embassy (KBRI) in the local of marriage place at least 30 days since the parties return to Indonesia, this is according to the article 37 paragraph 4 of act number 23 of 2006 on the citizen administration. A marriage witnessed by the embassy official or consulate official abroad, the notifications to the consulate or embassy representative of republic indoneisa at least 10 days before the marriage perform ${ }^{17}$, the registration by an abroad official does not means directly registrated in the civil registration

15 Peraturan Presiden nomor 25 tahun 2008 tentang Persyaratan dan Tata Cara Pendaftaran Penduduk dan Pencatatan Sipil Article 71 ayat 2

16 Peraturan Presiden nomor 25 tahun 2008 tentang Persyaratan dan Tata Cara Pendaftaran Penduduk dan Pencatatan Sipil Article 70 ayat 3

17 Peraturan Pemerintah no 9 tahun 1975 tentang Pelaksanaan Undang Undang nomor 1 tahun 1974, Article 3 ayat 2 
office of the parties, because the act regulated that after the return of the couple to Indonesia, in one year of the marriage must be registrated in the marriage registration office.

When arrive in Indonesia, then the Indonesian citizen couple or one of the Indonesian citizen who performed marriage aabroad must do the registration. So for that the article 56 of marriage act determines as follows:

1. The marriage in Indonesia between two Indonesian citizen or one of the Indonesian citizen with foreign citizen is legal if done according to the law of the state where the marriage occurred and for the Indonesian citizen by not violate this provision.

2. In one year after the husband and wife return to Indonesia, the marriage proof must be registered in the office of marriage registraration of the domicile.

The marriage act (UUP) considers legitimate of the mix marriage which held abroad if it has fulfill two of the requirements, which are according to the local state laws and indonesia marriage act (UUP) by following the Indonesian citizen who do the marriage. the registration of marriage also must be done when they return to Indonesia as a government control facilities to oversee its citizen. if the party does not registrate their marriage it is still legitimate but does not have the law bind (law power) in Indonesia.

The marriage between Indonesian citizen and foreign citizen is a personal rights for everybody which cannot be bothered. Living together betqeen mand woman who have satisfied the pqricular requierement. The nature and basic conspection of marriage is different in every country, where the differences depend on the legal system which followed by each country. The legal consequences of the marriage is linked with if its legitimate or not. If the marriage is not legal then the marriage is not legitimate as well as the marriage agreement. In order to determine if the marriage is legitimate or not as well as the marriage agreement then it shoukd be refer to the articles which related with act number 1 of 1974. Marriage registration is one of the process in purpose to have discipline administration which further recorded by the marriage registrar. This requirement as the administration requirement which if one day occure conflict of the marriage until it reach a divorce, the the office of religious affair and the office of civil registration as well as the marriage agreement of the couple able to held divorce process without having any significant obstacles to the divorce.

Concerning the purpose of the marriage registration under this marriage act is not specify further, only on the general explanation stated that the records of marriages is the same as the records of important event of the people live, such as birth, death which stated on the letters. The explanation of a formal deed which also loaded on the listing. Through 
understanding the general explanation it can be said that the marriage registration become clear whther for the concern party or other party, because it can be read on the formal letter and also loaded on the particular list as provided, so in any time it may able to use when needednas an authentic proof, and with the proof letter may be able to prevent from other action. A marriage registration does not determines whether a marriage is legitimate or not, but only saying that a marriage event was occurred solely administrative.

There is no specific regulation and law in Indonesia which regulated the marriage agreement that made abroad, according to the writer the registration procedure of marriage agreement following the marriage registration. If the couple never do the marriage registration at representative of Indonesia abroad then the marriage deed cannot be registrated and authorized under Indonesia law. The deed will become null and void so that it must be redefined as regulated under Indonesian law.

The marriage agreement which made abroad only authorized if the marriage frecord have been done according to the law in Indonesia. The marriage recrd following on how the marriage record. The rcords of quote of marriage deed and marriage agreement then translated into bahasa then legalize in notary and after that recorded in the office of religious affairs or civil registrar.

\section{CONCLUSION}

According to the discussion above it can be concluded that :

1. The authority on marriage authorization divided into:

1) An official of marriage registrar which are civil registrar and the official of religious affairs

2) A notary

The nature of marriage agreement that made abroad is like under hand deed and needs to be processed so that the marriage agreement may applicable in Indonesia. The process is done by legalise in front of notary and then do the registration at the marriage registrar which is the official of religiou s affairs for the moeslim couple or civil regsgistrar for the non moeslim, therefore the deed is authorized and applicable for the parties as well as the third party including everything on the agreement.

2. The mechanism on marriage agreement registration that made abroad is following the marriage deed record. The quote of marriage deed and marriage agreement is translated into bahasa then legalize to the notary after registrated in the official of religious affair and civil register. 


\section{BIBLIOGRAPHY}

\section{Books}

Abdul kadir Muhammad.(1992). Hukum Perikatan, Bandung: Citra Aditya.

Ahmad Rifai.(2010). Penemuan Hukum Oleh Hakim Dalam Persfektif Hukum Progresif, Jakarta: Sinar Grafika.

Amiruddin dan H. Zainal Asikin.(2008). Pengantar Metode Penelitian Hukum, Edisi ke-1 Cet IV, Jakarta: Raja Grafindo Persada.

Hamzah Halim \& Kemal Redindo Syahru Putera.(2010). Cara Praktis Menyusun \& Merancang Peraturan Daerah, Jakarta: Kencana Perdana Media Grup.

Indroharto.(1993). Usaha Memehami Undang-Undang Tentang Peradilan Tata Usaha Negara, Jakarta: Sinar Harapan.

Jazim Hamidi.(2006). Hukum Keimigrasian Bagi Orang Asing di Indonesia, Jakarta: Sinar Grafika.

Komar Andasasmita.(1990). Notaris II Contoh Akta Otentik dan Penjelasannya, Bandung: Ikatan Notaris Indonesia (INI), Cetakan Kedua.

Musthofa Sy.(2015). Dualisme Kewenangan Pencatatan Perceraian, Malang: Intelegensia Media.

Peter Mahmud Marzuki.(2010). Penelitian Hukum, Edisi ke-1 Cet VI, Jakarta: Kencana.

R. Subekti, R. Tjitrosudibio.(1978). Kitab Undang-Undang Hukum Perdata, Jakarta: Pradnya Paramita.

Racmad Safaat.(2009). Lapisan Lapisan Dalam Studi Hulum, Malang: Banyumedia Publishing.

Riduan Syahrani.(2006). Seluk-Beluk Dan Asas-Asas Hukum Perdata, Bandung: PT Alumni.

Sadjono, Bab-Bab Hukum Administrasi, Malang: Laksbang Presindo.

Satjipto Raharjo.(2012). Refreksi Dan Rekontruksi Ilmu Hukum Indonesia, Yogjkarta, Thafa Edia.

SF Marbun, Peradilan Administrasi Negara dan Uupaya Administrasi di Indonesia, Jogjakarta: Liberty.

Soetojo Prawirohamidjojo dan Asis Safiodien.(1987). Hukum Orang dan Keluarga, Bandung: Alumni, Cetakan V.

Subekti.(1983). Pokok-Pokok Hukum Perdata, Jakarta: PT Intermasa.

Sudargo Gautama.(1998). Hukum Perdata Internasonal Indonesia, Jakarta: Alumni.

Suharnoko.(2000). Hukum Perjanjian Teori dan Analisis Kasus , Jakarta: kencana. 
Supani.(2015). Diskursus Pencatatan Perkawinan, Yogjakarta: Dee Publish.

Tan Thong Kie, Studi Notariat Serba-Serbi praktek Notaris, Bandung: Press Media.

Tim Prima Pena.(1993). Kamus Lengkap Bahasa Indonesia, Jakarta: Gitamedia Press.

Wahyono Darmabrata dan Surini Ahlan Sjarif.(2004). Hukum Perkawinan dan Keluarga diIndonesia, Cetakan Kedua, Jakarta : Fakultas Hukum Universitas Indonesia.

Wiryono Prodjodikoro.(1991). Hukum Perkawinan Indonesia, Bandung: Alumni.

\section{Legislation}

Undang-Undang Dasar 1945.

Kitab Undang-Undang Hukum Perdata.

Undang Undang Perkawinan No 1 Tahun 1974.

Undang-Undang Nomor 23 Tahun 2006 Tentang Administrasi Kependudukan.

\section{Website}

http://www.indonesianotarycommunity.com/perjanjian-perkawinan/ accessed on desember $10^{\text {th }} 2017$.

http://www.mixedcouple.com, accessed on desember $9^{\text {th }} 2017$. 